\title{
Drug therapy for bone metastasis of malignant tumor: theory, progress, and potential
}

\author{
Minireview \\ Ji-Zheng TIAN, Ni-Na MA, Xiao LI, Kun SHANG, Bang-Wei CAO* \\ Cancer Center, Beijing Friendship Hospital, Capital Medical University, Beijing, China \\ ${ }^{*}$ Correspondence: oncology@ccmu.edu.cn
}

Received October 6, 2021 / Accepted December 29, 2021

\begin{abstract}
Bone is a common metastatic site of malignancies, caused by the complex interaction between tumor cells and the bone microenvironment. The complicated procedure covers multiple targets for therapeutic strategies against bone metastasis. At the present, only bisphosphonates and denosumab are currently approved for the prevention of skeletal-related events. But it is still ineffective for some patients, and none of them are proven to prolong the overall survival of patients with bone metastasis. Thus, new bone-modifying agents and therapeutic strategies are required. The review aimed to generalize the basic theory of bone metastasis and major put emphasis on the development of fundamental and potential target drugs in the behavior of bone metastasis. The summary of the drug development process helps to provide ideas for finding new and effective treatments for bone metastasis.
\end{abstract}

Key words: bone metastasis, bone microenvironment, bone-modifying agents, skeletal-related events

Bone is a major metastatic site of malignancies, such as breast cancer, prostate cancer, lung cancer, etc. [1]. Bone metastasis is divided into osteolytic metastasis with excessive bone resorption and osteoblastic metastasis with excessive bone formation. Bone metastasis can cause skeletal-related events (SREs), including bone radiotherapy, pathological fractures, spinal cord compression, surgery to bone, and hypercalcemia [2], which result in a poor prognosis and increase the economic burden.

The treatment of bone metastasis mainly includes bone modification drugs, radiotherapy, and surgery. The role of radiotherapy is mainly to relieve pain and increase strength, and the purpose of surgery is mainly to prevent disability. Bone-modifying drugs (BMAs) can be used throughout the entire process of treatment of bone metastasis to decrease the incidence of SREs. At present, just bisphosphonates and denosumab are currently approved for the prevention of SREs. But it is still vain for some patients, and not any of them are proved to prolong the overall survival of patients with bone metastasis. Thus, the development of new agents and new strategies are key to improve the treatment of bone metastasis. After decades of effort, the mechanism of bone metastasis has gradually been elucidated and drugs of different mechanisms are continuously emerging.

In this review, we would like to briefly summarize the basic theory of bone metastasis and put an emphasis on the key drugs and potential therapeutic interventions of bone metastasis.

\section{The mechanism of bone metastasis}

At present, the mechanism of bone metastasis is not clear. The "seed and soil" theory believed that the interaction between tumor cells and bone microenvironment plays an important role in tumor cells colonizing bone [3]. Emerging evidence has shown that primary tumor cells, bone marrowderived myeloid cells (BMDCs) contribute to form the pre-metastatic niche (PMN) by releasing tumor-specific growth factors, inflammatory cytokines, chemokines, angiogenesis factors, etc. $[4,5]$, which is beneficial to the colonization and growth of tumor cells. Then, disseminated tumor cells (DTCs) in the bone matrix and bone marrow stroma interact with osteoclasts and osteoblasts resulting in bone destruction. Bone destruction produces bone-derived 
cytokines such as insulin-like growth factors (IGFs) and transforming growth factor-beta (TGF- $\beta$ ), which are beneficial to the growth and invasion of tumor cells in bone tissue in turn. This is a "vicious circle" [6]. Therefore, the formation of the "vicious circle" is the key in the therapy of bone metastasis.

\section{Bone normal physiology and bone metastasis pathology}

Bone normal physiology depends on the dynamic balance between bone resorption by osteoclasts and bone formation by osteoblasts. Preclinical studies have confirmed several signaling pathways involved in osteogenesis and osteoclastogenesis (Figure 1). Metastatic tumor cells break the balance of osteoclasts and osteoblasts resulting in a "vicious circle". Herein, we reviewed the process of bone normal physiology and the "vicious circle" to provide a theoretical basis for the introduction of drug development.

Bone normal physiology. When bone is aged or damaged, osteoclast precursors differentiate into active osteoclasts via macrophage colony-stimulating factor (MCSF) and the receptor activator for nuclear factor- $\kappa \mathrm{B}$ ligand (RANKL) [7]. RANKL is a member of the tumor necrosis factor (TNF) family, produced by osteocytes, osteoblasts, and bone marrow stromal cells. RANKL binds to the receptor activator of nuclear factor- $\kappa \mathrm{B}$ (RANK) on osteoclast precursors surface to trigger the activation of osteoclasts. Osteoprotegerin (OPG), a decoy receptor from osteoblasts, binds to RANKL and inhibits the RANK/RANKL signaling pathway, blocking excessive activation of osteoclasts [8-10] (Figure 1). Activated osteoclasts mediate bone resorption by expressing cathepsin $\mathrm{K}$ [11].

Bone resorption induces the release of factors like TGF- $\beta$, bone morphogenetic proteins (BMPs) from the bone matrix, which facilitate differentiation of mesenchymal stem cells (MSCs) into osteoblasts $[12,13]$. Then, bone formation is activated. At the same time, osteocytes secrete sclerostin (SOST) and dickkopf1 (DKK1) to prevent excessive bone formation by blocking the WNT pathway [14] (Figure 1). Bone normal physiology depends on the balance between bone resorption and bone formation.

Pathology of osteolytic metastasis. Tumor-derived cytokines, such as IL-6, IL-8, IL-11, PTHrP, upregulate the expression of RANKL and downregulate the expression of OPG $[15,16]$. Tumor cells also secrete MCSF [17] to promote osteoclasts differentiation and bone resorption. The activation of osteoclasts degrades the bone matrix leading to the release of numerous growth factors, such as TGF- $\beta$, IGFs, and $\mathrm{Ca}^{2+}$, thus stimulating tumor cell proliferation [18]. On the other hand, tumor cells also inhibit osteoblast differentiation by secreting SOST and DKK1 [19]. All processes establish a "vicious circle" as described above (Figure 2).

Pathology of osteogenic metastasis. Osteogenic metastasis mainly occurs in advanced prostate cancer. The mechanism is not clear. Tumor-derived cytokines, such as endothelin-1 (ET-1) [20], BMPs, Wnt-family proteins (Wnts), TGF- $\beta$, are proved to promote osteoblast differentiation and osteogenesis (Figure 2). ET-1 downregulates
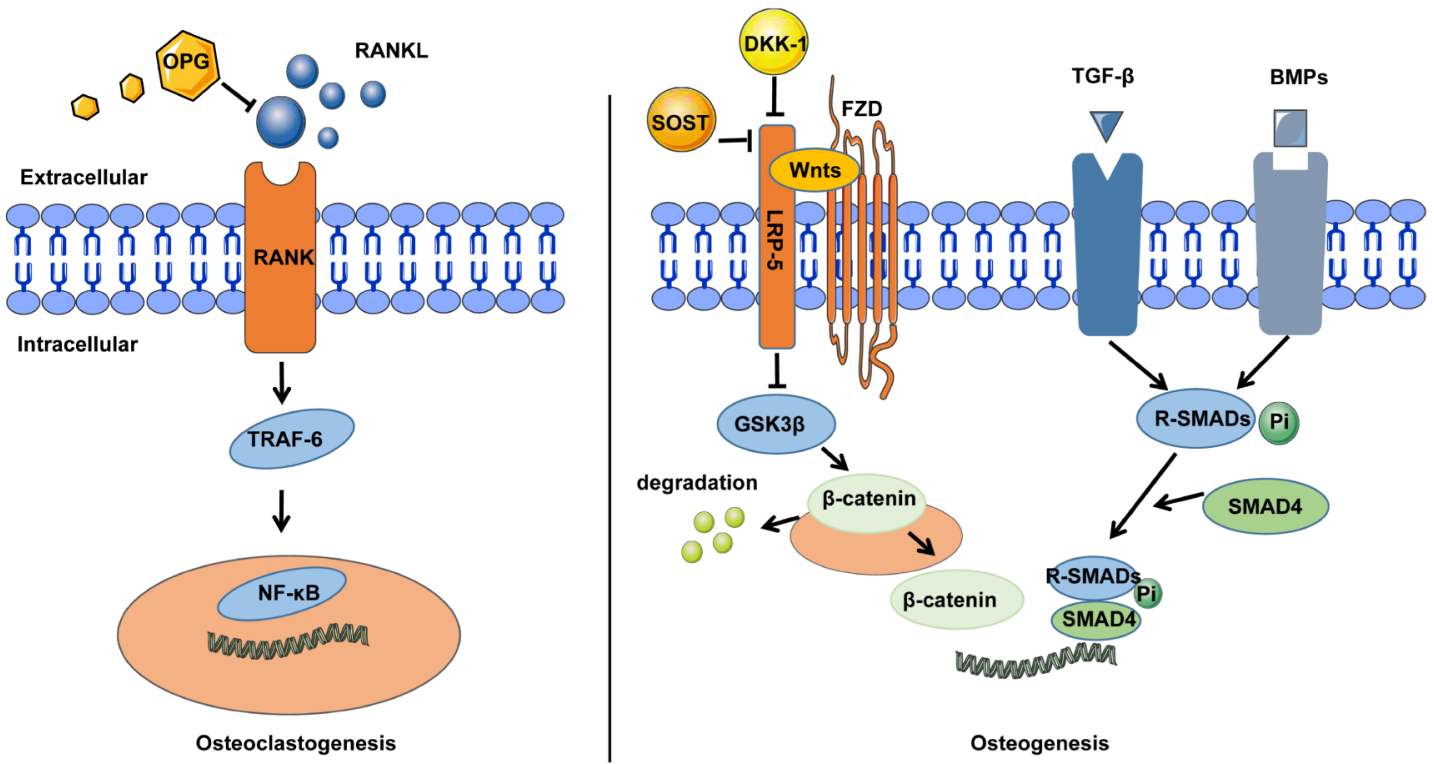

Figure 1. The signal pathway in osteoclastogenesis and osteogenesis. Abbreviations: OPG-osteoprotegerin; RANKL-receptor activator for nuclear factor- $\kappa$ B ligand; RANK-receptor activator of nuclear factor- $\mathrm{kB}$; TRAF-6-tumor necrosis factor receptor-associated factor 6; NF- $\mathrm{kB}$-nuclear factor $\mathrm{\kappa B}$; SOST-sclerostin; DKK-1-dickkopf-1; Wnts-Wnt-family proteins; FZD-frizzled; LRP-5-low-density lipoprotein-related receptor-5; GSK3 $\beta$-glycogen synthase kinase $3 \beta$; TGF- $\beta$-transforming growth factor- $\beta$; BMPs-bone morphogenetic proteins; SMAD4-mothers against decapentaplegic homolog 4 ; R-SMADs receptor-regulated Smads 


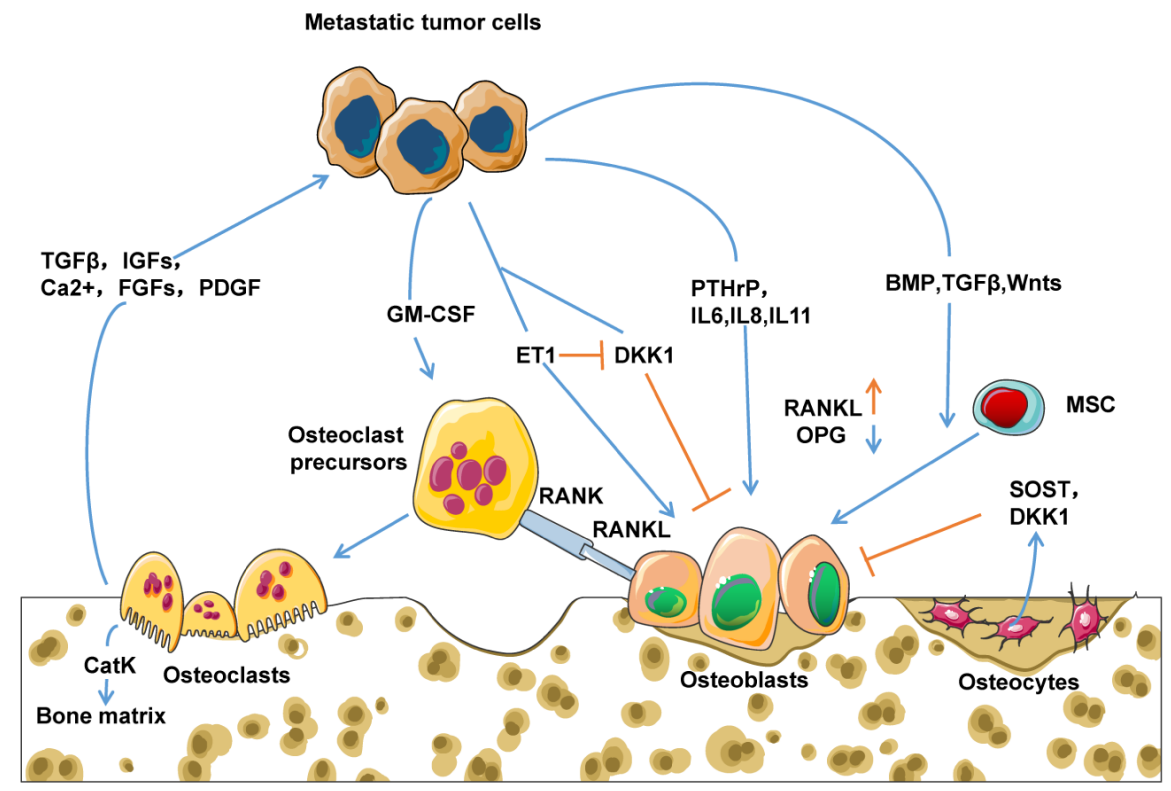

Figure 2. The development of bone metastasis and vicious cycle. Abbreviations: TGF- $\beta$-transforming growth factor- $\beta$; IGFs-insulin-like growth factors; FGFs-fibroblast growth factors; PDGF-platelet-derived growth factor; GM-CSF-granulocyte-macrophage colony-stimulating factor; ET-1-endothelin-1; PTHrP-parathyroid hormone-related protein; BMP-bone morphogenetic protein; TGF- $\beta$-transforming growth factor- $\beta$; Wnts-Wnt-family proteins; MSC-mesenchymal stem cell; OPG-osteoprotegerin; RANKL-receptor activator for nuclear factor- $\mathrm{B}$ ligand; RANK-receptor activator of nuclear factor-kB; SOST-sclerostin; DKK-1-dickkopf-1; CatK-cathepsin K

the autocrine production of DKK1 and promotes osteoblast differentiation via binding to the endothelin A receptor (ETR), activating Wnt signaling. ET-1 can also inhibit bone resorption to promote osteogenesis. BMPs and TGF- $\beta$ promote osteoblast differentiation via the SMAD signaling pathway [21] (Figure 1).

\section{The validated BMAs}

The currently validated BMAs include bisphosphonates and denosumab, a RANKL inhibitor, both of which mainly act on osteoclasts. In the past decades, bisphosphonates and denosumab have elicited tremendous attention because of their success in achieving long-term durable responses. They have been proved to reduce and prolong the occurrence of SREs. Although there is no sufficient evidence to prove that bisphosphonates and denosumab can prolong the overall survival of patients, they are still the standard drugs of bone metastasis.

\section{Bisphosphonates}

Bisphosphonates have a very high affinity for hydroxyapatite crystals and can effectively suppress bone resorption by inhibiting hydroxyapatite breakdown. Based on this preclinical rationale, three generations of bisphosphonates entered the clinical development (Table 1). These results provided sufficient data support for the prevention of SREs [22-35].
The first generation is represented by Clodronate (CLO). Early reports of two controlled trials showed CLO could relieve bone pain in patients with breast cancer and prostate cancer $[36,37]$. A double-blind controlled trial in patients with bone metastasis secondary to breast cancer who was randomized treated with CLO $(1.6 \mathrm{~g} / \mathrm{d})$ or placebo demonstrated that the combined rate of all SREs was remarkably reduced (218.6 vs. $304.8 / 100$ patient-years; $\mathrm{p}<0.001)$ [22]. Another randomized trial about metastatic breast cancer with bone involvement indicated that oral CLO $(600 \mathrm{mg} / \mathrm{bid})$ could significantly prolong the time to the first SRE than the control group $(\mathrm{p}=0.015)$ and the incidence of fractures was significantly reduced in the CLO group ( $\mathrm{p}=0.023$ ) [23].

Pamidronate is a second-generation agent. Combine data from two randomized controlled studies show Pamidronate (90 mg/3-4 w) was superior to placebo in patients with osteolytic bone metastasis from breast cancer [25]. The skeletal morbidity rate was lower in the Pamidronate group compared with placebo (2.4 vs. 3.7; $\mathrm{p}<0.001)$. The incidence of SREs was $51 \%$ in the Pamidronate group and $64 \%$ in the placebo group $(p<0.001)$. Additionally, Pamidronate significantly increased median time to first SRE (12.7 vs. 7 months for placebo; $\mathrm{p}<0.001)$. Unfortunately, the data of head-to-head comparison with the first-generation drugs are missing, and no prospective randomized controlled study on prostate cancer has been designed, although Pamidronate is effective in the clinic. 
Table 1. Clinical trials of bisphosphonates in patients with bone metastasis.

\begin{tabular}{|c|c|c|c|c|}
\hline Agent & Patients & Dose & Results & Ref. \\
\hline \multicolumn{5}{|l|}{ Clodronate } \\
\hline vs. Placebo & Breast cancer & $1.6 \mathrm{~g} / \mathrm{d}$ & $\begin{array}{l}\text { The combined rate of all morbid SREs } \downarrow \\
(\mathrm{p}<0.001)\end{array}$ & {$[22]$} \\
\hline vs. No-treatment & Breast cancer & $800 \mathrm{mg}$ bid po & $\begin{array}{l}\text { the time to the first SRE } \rightarrow \\
(\mathrm{p}=0.015)\end{array}$ & [23] \\
\hline \multicolumn{5}{|l|}{ Pamidronate } \\
\hline vs. Placebo & Breast cancer & $60 \mathrm{mg} / 4 \mathrm{w}$ & $\begin{array}{l}\text { Cumulative number of SREs } \downarrow \\
(\mathrm{p}<0.01)\end{array}$ & [24] \\
\hline vs. Placebo & Breast cancer & $90 \mathrm{mg} / 3-4 \mathrm{w}$ & $\begin{array}{l}\text { The skeletal morbidity rate } \downarrow \\
(\mathrm{p}<0.001) \\
\text { SREs } \downarrow \\
(\mathrm{p}<0.001) \\
\text { The median time to first SRE } \rightarrow \\
(\mathrm{p}<0.001)\end{array}$ & [25] \\
\hline \multicolumn{5}{|l|}{ Zoledronic acid } \\
\hline vs. Placebo & Renal cell carcinoma & 4 or $8 \mathrm{mg} / 3 \mathrm{w}$ & $\begin{array}{l}\text { The proportion of patients with an SRE } \downarrow \\
\text { ( } \mathrm{p}=0.015 \text { ) } \\
\text { The time to the first SRE } \rightarrow \\
(\mathrm{p}=0.006 \text { ) }\end{array}$ & [26] \\
\hline vs. Pamidronate & $\begin{array}{l}\text { Breast cancer } \\
\text { Multiple myeloma }\end{array}$ & $4 \mathrm{mg} / 3-4 \mathrm{w}$ vs. $90 \mathrm{mg} / 3-4 \mathrm{w}$ & $\begin{array}{l}\text { the overall risk of developing SREs } \downarrow \\
\text { ( } \mathrm{p}=0.030 \text { ) } \\
\text { The risk of SREs in breast cancer } \downarrow \\
\text { ( } \mathrm{p}=0.025 \text { ) }\end{array}$ & [27] \\
\hline vs. Placebo & Prostate cancer & $4 \mathrm{mg} / 3 \mathrm{w}$ & $\begin{array}{l}\text { The annual incidence of SREs } \downarrow \\
\text { ( } p=0.005 \text { ) } \\
\text { The median time to the first SRE } \rightarrow \\
\text { ( } p=0.009 \text { ) } \\
\text { The ongoing risk of SREs } \downarrow \\
\text { ( } p=0.002 \text { ) }\end{array}$ & [28] \\
\hline vs. CLO & Prostate cancer & $\begin{array}{l}4 \mathrm{mg} / \mathrm{m} \\
\text { vs. } 1.6 \mathrm{~g} / \mathrm{d}\end{array}$ & $\begin{array}{l}\text { Bone progression-free survival } \uparrow \\
(\mathrm{p}=0.04)\end{array}$ & [29] \\
\hline vs. Placebo & Lung cancer and other solid tumors & 4 or $8 \mathrm{mg} / 3 \mathrm{w}$ & $\begin{array}{l}\text { The median time to first SRE } \rightarrow \\
(\mathrm{p}=0.009) \\
\text { The annual incidence of SREs } \downarrow \\
\text { ( } \mathrm{p}=0.012) \\
\text { The risk of developing a SRE } \downarrow \\
\text { ( } \mathrm{p}=0.003 \text { ) }\end{array}$ & [30] \\
\hline \multicolumn{5}{|l|}{ Oral Ibandronate } \\
\hline vs. Placebo & Breast cancer & 20 or $50 \mathrm{mg} / \mathrm{d}$ & $\begin{array}{l}\text { Skeletal morbidity period rate } \downarrow \\
(\mathrm{p}=0.024, \mathrm{p}=0.037) \\
\text { The relative risk of SREs } \downarrow \\
(\mathrm{p}=0.009 \text { and } \mathrm{p}=0.005)\end{array}$ & [31] \\
\hline vs. Placebo & Breast cancer & $50 \mathrm{mg} / \mathrm{d}$ & $\begin{array}{l}\text { Skeletal morbidity period rate } \downarrow \\
\text { ( } \mathrm{p}=0.004 \text { ) } \\
\text { The risk of SREs } \downarrow \\
(\mathrm{p}=0.0001)\end{array}$ & {$[32]$} \\
\hline vs. ZOL & Breast cancer & $50 \mathrm{mg} / \mathrm{d}$ vs. $4 \mathrm{mg} / 3-4 \mathrm{w}$ & Annual rates of SREs non-inferiority & [33] \\
\hline \multicolumn{5}{|l|}{ Ibandronate } \\
\hline vs. Placebo & Colorectal carcinoma & $6 \mathrm{mg} / 4 \mathrm{w}$ & $\begin{array}{l}\text { The proportion of patients with SREs } \downarrow(p=0.019) \\
\text { The time to first SRE } \rightarrow \\
(p=0.009)\end{array}$ & {$[34]$} \\
\hline vs. Placebo & Breast cancer & $6 \mathrm{mg} / 4 \mathrm{w}$ & $\begin{array}{l}\text { The proportion of patients with an SRE } \downarrow \\
\text { ( } p=0.027) \\
\text { Time to first SRE } \rightarrow \\
(p=0.007)\end{array}$ & [35] \\
\hline
\end{tabular}


Zoledronic acid (ZOL), a third-generation agent, has demonstrated highly durable response rates of several large phase III studies involving patients with bone metastasis in advanced breast cancer, prostate cancer, renal cell carcinoma, lung cancer, and other solid tumors (Table 1). In a randomized double-blind multicenter trial of ZOL (4 or $8 \mathrm{mg}$ ) vs. Pamidronate $(90 \mathrm{mg}), \mathrm{ZOL}(4 \mathrm{mg})$ significantly reduced the risk of SREs $(\mathrm{p}=0.025)$ compared with the Pamidronate group of patients with breast cancer [27]. The median time to first SRE was no statistically different between the two groups. However, subgroup analysis showed in breast cancer with hormonal therapy, ZOL (4 mg) prolonged the median time to the first SRE by 45 days ( 415 days vs. 370 days for Pamidronate; $\mathrm{p}=0.047)$. Additionally, another randomized placebo-controlled trial demonstrated the benefit of ZOL in the management of bone metastasis from advanced prostate cancer [38]. The result of 122 patients who completed a total of 24 months on study illustrated the median time to the first SRE was significantly prolonged in ZOL (4 mg) (488 days vs. 321 days for placebo; $\mathrm{p}=0.009$ ). Based on the above research, $\mathrm{ZOL}$ is the most well-demonstrated bisphosphonate in prostate cancer and is also the most widely used bisphosphonate in clinical practice.

Ibandronate is another third-generation agent. In a non-inferiority phase 3 trial of bone metastasis from breast cancer, the findings could not reject the null hypothesis that oral Ibandronate $(50 \mathrm{mg} / \mathrm{d})$ was inferior to ZOL $(4 \mathrm{mg} / 3-4 \mathrm{w})$. The notable result was that the incidence of renal toxic effects was $24 \%$ in the oral ibandronate group and $32 \%$ in the ZOL group [33]. Ibandronate was also evaluated in a random- ized placebo-controlled pilot study, enrolling 73 patients with bone metastasis from colorectal carcinoma (CRC) [34]. Patients randomly received intravenous ibandronate $(6 \mathrm{mg})$ every 4 weeks or a placebo. The results demonstrated that the proportion of patients with SREs was significantly reduced in the ibandronate group ( $39 \%$ vs. $78 \%$ with placebo; $\mathrm{p}=0.019$ ) and the time to first SRE is extended by at least 6 months (median $>279$ vs. 93 days with placebo; $\mathrm{p}=0.009$ ). One of our studies confirmed that the loading dose of Ibandronate (6 $\mathrm{mg}$ for three days) has certain advantages in reducing bone pain [39]. Although Ibandronate has not shaken the status of ZOL, it also provides a new option, especially in oral dosage forms.

Bisphosphonates are basic drugs recommended by guidelines for the treatment of bone metastasis. However, renal toxicity and the high incidence of osteonecrosis of the jaw (ONJ) have always been troubled issues in clinical practice. Therefore, we need drugs with few side effects.

\section{RANKL inhibitor}

Denosumab is the first anti-RANKL antibody approved for marketing. As a fully human anti-RANKL IgG2 antibody, Denosumab can suppress the activation of osteoclasts and prevent bone resorption by inhibiting the RANK/RANKL signaling pathway. Several studies confirmed the role of Denosumab in bone metastasis (Table 2).

In three presented randomized phase III studies, Denosumab (120 mg/4 w) was superior to ZOL (4 mg/4 w) in delaying time to first on-study SRE with advanced breast

Table 2. Current data of denosumab versus ZOL in patients with bone metastasis.

\begin{tabular}{|c|c|c|c|}
\hline Patient population & Type of study & Results & Ref. \\
\hline $\begin{array}{l}\text { Breast cancer } \\
\mathrm{N}=2046\end{array}$ & RCT & $\begin{array}{l}\text { Median time to first SRE: NoR vs. } 26.4 \text { months; } \mathrm{p}=0.01 \\
\text { Overall survival: HR } 0.95 ; 95 \% \text { CI:0.81 to } 1.11 ; \mathrm{p}=0.49\end{array}$ & {$[40]$} \\
\hline $\begin{array}{l}\text { Prostate cancer } \\
\mathrm{N}=1904\end{array}$ & RCT & $\begin{array}{l}\text { Median time to first SRE: } 20.7 \text { vs. } 17.1 \text { months; } \mathrm{p}=0.008 \\
\text { Overall survival: HR } 1.03 ; 95 \% \text { CI: } 0.91 \text { to } 1.17 ; \mathrm{p}=0.65\end{array}$ & [41] \\
\hline $\begin{array}{l}\mathrm{MM} \\
\mathrm{N}=1718\end{array}$ & RCT & $\begin{array}{l}\text { Median time to first SRE: } 22.8 \text { vs. } 24.0 \text { months; } \mathrm{p}=0.010 \\
\text { Overall survival: HR } 0.90 ; 95 \% \text { CI:0.70 to } 1.16 ; \mathrm{p}=0.41\end{array}$ & [42] \\
\hline $\begin{array}{l}\text { Other solid tumors } \\
\text { (Excluding BC and PC) } \\
\text { or MM } \\
\mathrm{N}=1776\end{array}$ & RCT & $\begin{array}{l}\text { Median time to first SRE: } 20.6 \text { vs } 16.3 \text { months; } p=0.06 \\
\text { Overall survival: HR } 0.95 ; 95 \% \text { CI: } 0.83 \text { to } 1.08 ; p=0.43\end{array}$ & [43] \\
\hline $\begin{array}{l}\text { Solid tumors } \\
\text { (Except BC and PC) } \\
\mathrm{N}=1597\end{array}$ & Subgroup analysis of RCT & $\begin{array}{l}\text { Median time to first SRE: } 21.4 \text { vs. } 15.4 \text { months; } \mathrm{p}=0.017 \\
\text { Overall survival: HR } 0.92 ; 95 \% \text { CI:0.81 to } 1.05 ; \mathrm{p}=0.215\end{array}$ & {$[44]$} \\
\hline $\begin{array}{l}\text { Solid tumors and } \mathrm{MM} \\
\mathrm{N}=5723\end{array}$ & Combined analysis of 3 RCTs & $\begin{array}{l}\text { Median time to first SRE: } 27.66 \text { vs. } 19.45 \text { months; } \mathrm{p}<0.001 \\
\text { Overall survival: HR } 0.99 ; 95 \% \text { CI:0.91 to } 1.07 ; \mathrm{p}=0.71\end{array}$ & [45] \\
\hline $\begin{array}{l}\text { Gastrointestinal cancer } \\
\text { and other rare cancer } \\
\mathrm{N}=149\end{array}$ & Retrospective study & Median time to SRE: 186 vs. 79 days; $p=0.0053$ & [46] \\
\hline $\begin{array}{l}\text { Lung cancer } \\
\mathrm{N}=411\end{array}$ & Subgroup analysis of RCT & $\begin{array}{l}\text { Overall survival: } 8.9 \text { vs. } 7.7 \text { months } \\
\text { HR } 0.80 ; 95 \% \text { CI: } 0.67 \text { to } 0.95 ; \mathrm{p}=0.01\end{array}$ & [47] \\
\hline $\begin{array}{l}\text { Non-squamous NSCLC } \\
\mathrm{N}=103\end{array}$ & Retrospective study & Overall survival: 21.4 vs. 12.7 months; $\mathrm{p}<0.01$ & [48] \\
\hline
\end{tabular}


cancer $(\mathrm{p}=0.01)$, prostate cancer $(\mathrm{p}=0.008)$, and multiple myeloma $(\mathrm{p}=0.010)[40,42]$. In another randomized phase III randomized involving patients with other advanced cancer (excluding breast and prostate cancer) and multiple myeloma, Denosumab was non-inferior to ZOL statistically $(p=0.06)[43]$. However, in a subgroup analysis of data from patients with solid tumors (except breast and prostate cancer), the median time to the first SRE was significantly prolonged in Denosumab (21.4 months vs. 15.4 months for ZOL; $\mathrm{p}=0.017$ ) [44]. A combined analysis of three RCTs also confirmed that Denosumab $(120 \mathrm{mg} / 4 \mathrm{w})$ can significantly prolong SREs in solid tumors and multiple myeloma $(p<0.001)$ [45]. Evidence of Denosumab in gastrointestinal cancer was provided by a retrospective study in Japan, the result showed patients had benefited from Denosumab [46]. Unfortunately, Denosumab was not found overall survival better than ZOL above. Although a result of subgroup analysis from patients with lung cancer showed the median time of overall survival is prolonged by 1.2 months in Denosumab (8.9 vs. 7.7 months for ZOL; $\mathrm{p}=0.01$ ) [47], and a retrospective study of non-squamous NSCLC observed the advantage of survival [48], more prospective data are needed to confirm the survival advantage.

On the other hand, clinical trials above had proved that denosumab was superior to ZOL in terms of renal toxicity. However, the incidence of $\mathrm{ONJ}$ is still high. Given that bisphosphonates and Denosumab are anti-bone resorptions, developing drugs with other mechanisms may prevent this trouble.

\section{Other clinical trials of unapproved agents}

Some other drugs are in clinical research, including antibone resorption agents and anti-bone formation agents. Although the results of preclinical studies are exciting, they have not brought adequate evidence for the treatment of bone metastasis. Some drugs are effective in the treatment of osteoporosis, but they cannot be confirmed in bone metastasis. The main reason is the difference in the bone microenvironment.

Cathepsin K inhibitors. Cathepsin K (CTSK) is a lysosomal cysteine protease secreted by activated osteoclasts, which could effectively mediate bone resorption by degrading type I collagen, type II collagen, and exciting matrix-metalloproteinase-9 (MMP-9) [49-51]. Therefore, CTSK inhibitors can prevent bone resorption theoretically. However, there are no approved agents for bone metastasis so far.

Odanacatib (ODN-MK-0822) was the first drug to show therapeutic effects in reducing the fracture risk of postmenopausal osteoporosis patients in the LOFT study but was associated with a high risk of cardiovascular events [52]. In vitro studies demonstrated that ODN-MK-0822 could inhibit invasion, migration and adhesion of human breast cancer cells [53] and decrease the mRNA expression of secreted pro-osteoclast factors [54]. In a randomized 2:1 study, Odanacatib (5 mg/d) suppressed uNTx equivalently to ZOL ( $4 \mathrm{mg} / 4 \mathrm{w}$ ) after 4 weeks of treatment in patients with bone metastasis of breast cancer [55]. There is no evidence of other CTSK inhibitors such as ONO-5334, AAE581, and MIV-711 in the treatment of bone metastasis.

c-Src inhibitors. c-Src is a non-receptor tyrosine kinase and is abundant in osteoclasts. Preclinical studies have proved c-Src plays an important role in cell proliferation, angiogenesis [56], and bone homeostasis [57]. c-Src affects the boneresorbing activity of mature osteoclasts by boosting the rapid assembly and disassembly of the podosomes [58]. Therefore, the c-Src inhibitor may prevent osteoclast-mediated bone resorption.

On the basis of this preclinical rationale, four c-Src inhibitors, Dasatinib, Bosutinib, Vandetanib, and Saracatinib, were involved in clinical studies of bone metastasis. In phase I/II study of breast cancer bone metastasis, Dasatinib combined with zoledronic acid was proven to be well tolerated and had responses in patients with HR-positive [59]. However, in the SWOG S0622 study, either of the 2 dose schedules of Dasatinib was unsuccessful to control bone metastasis in metastatic breast cancer [60]. Similarly, another phase II study of Dasatinib with weekly Paclitaxel also showed ineffectiveness in MBC [61]. With respect to metastatic castration-resistance prostate cancer (CRPC), the READY study showed the Dasatinib $(100 \mathrm{mg} / \mathrm{d})$ group had no significant benefit in delaying median time to first SRE (not reached vs. 31.1 months for placebo; $\mathrm{p}=0.81$ ) [62].

Other c-Src inhibitors, such as Bosutinib, Vandetanib, and Saracatinib, are also short of sufficient evidence of bone metastasis. Preclinical studies showed the ability of SKI-606 (Bosutinib) to block breast cancer and prostate cancer invasion, growth, and metastasis in vitro and in vivo [63-65]. Bosutinib could distinctly reduce tumor growth and lytic lesion areas in the bone by an animal model of prostate cancer [64]. Nevertheless, in a phase II study in patients with advanced breast cancer who pretreated with chemotherapy, Bosutinib did not change the level of bone resorption markers during the process of treatment [66]. In a randomized placebo-controlled study, Zamboney et al. showed that the addition of Vandetanib to Fulvestrant failed to prolong time to first SRE and change the biomarkers of bone turnover in hormone-receptor-positive metastatic breast cancer [67]. With respect to Saracatinib (AZD 0530), preclinical studies demonstrated Saracatinib (AZD 0530) could inhibit osteoclast formation effectively in vitro $[68,69]$ and prevent mice from developing severe osteolytic lesions in vivo studies [70]. The result of a phase I study showed Saracatinib significantly decreased the bone resorption markers of osteoclast activity in patients with advanced cancer [71]. However, further research showed that Saracatinib could not relieve bone pain effectively [72].

Integrin inhibitors. Integrins are heterodimeric cell surface receptors. Previous studies have established that integrins can mediate tumor cells' adhesion to the extracel- 
lular matrix (ECM) $[73,74]$ and facilitate the proliferation and invasion of tumor cells [75]. Moreover, numerous studies have attempted to explain the role of $\alpha v \beta 3$ in bone metastasis [76-78] and anti- $\alpha v \beta 3$ therapy can reduce bone resorption by inhibiting osteoclast adhesion in vitro $[79,80]$. Although initial enthusiasm for integrin inhibitors was generated from advanced cancers, the experience with integrin inhibitors in bone metastasis is less mature.

Cilengitide is a selective inhibitor of $\alpha v \beta 3$ and $\alpha v \beta 5$ integrins. A randomized phase II trial of metastatic castrationresistant prostate cancer patients was a failure of altering bone markers, so there were no further data about the bone disease [81].

MEDI-522 is another inhibitor of human $\alpha v \beta 3$ integrin. Unfortunately, a phase II study in patients with metastatic androgen-independent prostate cancer who experienced MEDI-522 in combination with Docetaxel, Prednisone, and ZOL did not present the result of the incidence of SREs.

ATN-161 and PSK 1404, nonpeptide antagonist of av $\beta 3$, could block bone metastasis and bone resorption in the animal model of breast cancer [82, 83].

The latest evidence showed that integrin alpha5 (ITGA5) is overexpressed in bone metastasis of breast cancer [84] and ITGA5 antibody (M200) decreased human osteoclastmediated bone resorption in vitro [84]. We hope the effect of M200 could be confirmed in vivo and in clinical trials in the future.

DKK1 inhibitors and SOST inhibitors. Wnt signaling bone formation pathway has emerged as a crucial factor in bone formation $[85,86]$. DKK1 and SOST was the antagonist of the Wnt signaling pathway as described above. Preclinical studies showed that inhibiting Dkk1 could prevent osteolytic disease in breast cancer and multiple myeloma [87, 88].

BHQ880 is a human anti-DKK1 monoclonal antibody. In a presented phase Ib study, BHQ880 in combination with zoledronic acid was effective in promoting bone mineral density (BMD) in MM [89]. A clinical trial of DKN-01, another new agent, is recruiting.

As regards SOST inhibitors, Romosozumab, Blosozumab, and BPS804 have been shown to result in disease responses in clinical trials of osteoporosis [90-92]. Unfortunately, researchers have not designed clinical trials on bone metastasis so far.

\section{Potential drugs}

Previous research has focused too much on bone resorption and reconstruction, which seems to ignore the role of the bone microenvironment. And the target is not accurate enough. Fortunately, scientists are constantly discovering new therapeutic targets, including bone-derived cytokines and new drug delivery systems, which have brought us positive signals.

Bone-derived growth factor inhibitors. Bonederived cytokines such as IGFs and TGF- $\beta$ and receptors played an important role in the "vicious circle" and epithelial-to-mesenchymal transition (EMT).

AZD3463, an IGF-1R inhibitor, suppresses bone metastasis of breast cancer via the PI3K-Akt pathway in vitro, especially when combined with ZOL [93].

TGF $\beta$ R inhibitors ZL170 and SD208 reduce bone metastasis of breast cancer and prostate cancer via blocking the TGF $\beta /$ SMAD pathway $[94,95]$. Given that growth factors are widely distributed in the human body, we need to develop more precise drugs to treat bone metastasis.

\section{Targeting hypoxic microenvironment}

The hypoxic microenvironment has emerging roles in the development of bone disease. Hypoxia plays a key role at all stages of bone metastasis. In vitro studies demonstrated that hypoxia promoted osteoclast formation by upregulating RANKL [96-98] and inhibited the differentiation of osteoblasts [99]. Hypoxia-inducible factor (HIF)-1 promoted the formation of PMN by regulating the expression of LOX [100, 101]. Targeting hypoxic microenvironment and HIF may a new treatment strategy for bone metastasis of malignant tumors.

CaSR inhibitors. The calcium-sensing receptor (CaSR) is a G-protein-coupled receptor. The function of CaSR is unequal in different tumors. CaSR is a protective receptor in colon cancer $[102,103]$. Otherwise, previous studies have confirmed that overexpression of the CaSR promotes bone metastasis in several tumors such as breast cancer, prostate cancer, lung adenocarcinoma, and renal cell carcinoma [104-107]. CaSR might be a potential therapeutic target of preventing bone metastasis. NPS2143, a CaSR antagonist, was proven to reduce bone metastasis in vitro and animal models in renal cell carcinoma [106].

Nanodrugs and conjugate drugs. Many potential drugs have not reached effective concentrations to treat bone metastasis. To achieve the therapeutic concentration in the bone, the treatment of bone metastasis with the most effective and minimal systemic toxicity requires new treatment strategies. Nanoparticles encapsulate therapeutic drugs, protect them from degradation, and can bind to specific sites to improve efficacy. Another strategy is traditionally anti-tumor drugs such as Paclitaxel and Bortezomib specifically anchored to the bone by coupling with bisphosphonates [108].

\section{Conclusion}

At present, most studies on the mechanism of bone metastasis are mainly focused on breast and prostate cancer. There are many unclear mechanisms of bone metastasis because each tumor has its own characteristics. This is the main reason for the failure of many drugs. The drugs approved for the treatment of bone metastasis are limited. Anti-bone resorption therapy with bisphosphonates and denosumab 
has improved the outlook for patients with bone metastasis in a variety of malignancies. Despite the benefit of this approach, many questions remain, such as not all patients respond to current agents, high incidence of osteonecrosis of the jaw, and no advantage in prolonging overall survival.

Therefore, further insight into the mechanisms of bone metastasis is needed, and new therapeutic strategies are required. With the continuous elucidation of tumor metastasis mechanism and innovation of anti-tumor therapy, we could focus our attention on the metastatic microenvironment, the formation of PMN, and the combined application of bone-targeted drugs and anti-tumor drugs, such as chemotherapy or immune checkpoint inhibitors. The therapy of bone metastasis will continue to be a challenge today and future.

Acknowledgments: We acknowledge and appreciate our colleagues for their valuable efforts and comments on this paper. This study was funded by the Beijing key clinical specialty (2018-2020 to $\mathrm{BC})$.

\section{References}

[1] COLEMAN RE. Clinical features of metastatic bone disease and risk of skeletal morbidity. Clin Cancer Res 2006; 12: 6243s-6249s. https://doi.org/10.1158/1078-0432.Ccr-060931

[2] D'ORONZO S, COLEMAN R, BROWN J, SILVESTRIS F. Metastatic bone disease: Pathogenesis and therapeutic options: Up-date on bone metastasis management. J Bone Oncol 2019; 15: 004-004. https://doi.org/10.1016/j. jbo.2018.10.004

[3] AKHTAR M, HAIDER A, RASHID S, AL-NABET A. Paget's "Seed and Soil" Theory of Cancer Metastasis: An Idea Whose Time has Come. Adv Anat Pathol 2019; 26: 69-74. https:// doi.org/10.1097/pap.0000000000000219

[4] WANG Y, DING Y, GUO N, WANG S. MDSCs: Key Criminals of Tumor Pre-metastatic Niche Formation. Front Immunol 2019; 10: 172. https://doi.org/10.3389/fimmu.2019.00172

[5] WANG M, XIA F, WEI Y, WEI X. Molecular mechanisms and clinical management of cancer bone metastasis. Bone Res 2020; 8: 30. https://doi.org/10.1038/s41413-020-00105-1

[6] WEILBAECHER KN, GUISE TA, MCCAULEY LK. Cancer to bone: a fatal attraction. Nat Rev Cancer 2011; 11: 411-425. https://doi.org/10.1038/nrc3055

[7] KUROTAKI D, YOSHIDA H, TAMURA T. Epigenetic and transcriptional regulation of osteoclast differentiation. Bone 2020; 138: 115471. https://doi.org/10.1016/j. bone. 2020.115471

[8] BOYCE BF, XING L. Biology of RANK, RANKL, and osteoprotegerin. Arthritis Res Ther 2007; 9 Suppl 1: S1. https://doi. org/10.1186/ar2165

[9] KENKRE JS, BASSETT J. The bone remodelling cycle. Ann Clin Biochem 2018; 55: 308-327. https://doi. org/10.1177/0004563218759371
[10] CHEN X, WANG Z, DUAN N, ZHU G, SCHWARZ EM et al. Osteoblast-osteoclast interactions. Connec Tissue Res 2018; 59: 99-107. https://doi.org/10.1080/03008207.2017.12 90085

[11] BONNET N, BRUN J, ROUSSEAU JC, DUONG LT, FERRARI SL. Cathepsin K Controls Cortical Bone Formation by Degrading Periostin. J Bone Miner Res 2017; 32: 1432-1441. https://doi.org/10.1002/jbmr.3136

[12] GRAFE I, ALEXANDER S, PETERSON JR, SNIDER TN, LEVI B et al. TGF- $\beta$ Family Signaling in Mesenchymal Differentiation. Cold Spring Harbor perspectives in biology 2018; 10. https://doi.org/10.1101/cshperspect.a022202

[13] GARG P, MAZUR MM, BUCK AC, WANDTKE ME, LIU J et al. Prospective Review of Mesenchymal Stem Cells Differentiation into Osteoblasts. Orthop Surg 2017; 9: 13-19. https://doi.org/10.1111/os.12304

[14] ROBLING AG, BONEWALD LF. The Osteocyte: New Insights. Annu Rev Physiol 2020; 82: 485-506. https://doi. org/10.1146/annurev-physiol-021119-034332

[15] SALAMANNA F, BORSARI V, CONTARTESE D, COSTA $\mathrm{V}$, GIAVARESI $\mathrm{G}$ et al. What Is the Role of Interleukins in Breast Cancer Bone Metastases? A Systematic Review of Preclinical and Clinical Evidence. Cancers 2019; 11: 2018. https://doi.org/10.3390/cancers11122018

[16] FAN Y, HANAI JI, LE PT, BI R, MARIDAS D et al. Parathyroid Hormone Directs Bone Marrow Mesenchymal Cell Fate. Cell Metab 2017; 25: 661-672. https://doi.org/10.1016/j. cmet.2017.01.001

[17] MARGULIES BS, DEBOYACE SD, DAMRON TA, ALLEN MJ. Ewing's sarcoma of bone tumor cells produces MCSF that stimulates monocyte proliferation in a novel mouse model of Ewing's sarcoma of bone. Bone 2015; 79: 121-130. https://doi.org/10.1016/j.bone.2015.05.041

[18] SO CL, SAUNUS JM, ROBERTS-THOMSON SJ, MONTEITH GR. Calcium signalling and breast cancer. Semi Cell Dev Biol 2019; 94: 74-83. https://doi.org/10.1016/j. semcdb.2018.11.001

[19] ZHUANG X, ZHANG H, LI X, LI X, CONG M et al. Differential effects on lung and bone metastasis of breast cancer by Wnt signalling inhibitor DKK1. Nat Cell Biol 2017; 19: 1274-1285. https://doi.org/10.1038/ncb3613

[20] GUISE TA, YIN JJ, MOHAMMAD KS. Role of endothelin-1 in osteoblastic bone metastases. Cancer 2003; 97: 779-784. https://doi.org/10.1002/cncr.11129

[21] TODD GM, GAO Z, HYVÖNEN M, BRAZIL DP, TEN DIJKE P. Secreted BMP antagonists and their role in cancer and bone metastases. Bone 2020; 137: 115455. https://doi. org/10.1016/j.bone.2020.115455

[22] PATERSON AH, POWLES TJ, KANIS JA, MCCLOSKEY E, HANSON J et al. Double-blind controlled trial of oral clodronate in patients with bone metastases from breast cancer. J Clin Oncol 1993; 11: 59-65. https://doi.org/10.1200/ jco.1993.11.1.59

[23] KRISTENSEN B, EJLERTSEN B, GROENVOLD M, HEIN S, LOFT $\mathrm{H}$ et al. Oral clodronate in breast cancer patients with bone metastases: a randomized study. J Intern Med 1999; 246 : 67-74. https://doi.org/10.1046/j.1365-2796.1999.00507.x 
[24] HULTBORN R, GUNDERSEN S, RYDEN S, HOLMBERG E, CARSTENSEN J et al. Efficacy of pamidronate in breast cancer with bone metastases: a randomized, double-blind placebo-controlled multicenter study. Anticancer Res 1999; 19: 3383-3392.

[25] LIPTON A, THERIAULT RL, HORTOBAGYI GN, SIMEONE J, KNIGHT RD et al. Pamidronate prevents skeletal complications and is effective palliative treatment in women with breast carcinoma and osteolytic bone metastases: long term follow-up of two randomized, placebo-controlled trials. Cancer 2000; 88: 1082-1090. https://doi.org/10.1002/ (sici) 1097-0142(20000301)88:5<1082::aid-cncr20>3.0.co;2-z

[26] LIPTON A, ZHENG M, SEAMAN J. Zoledronic acid delays the onset of skeletal-related events and progression of skeletal disease in patients with advanced renal cell carcinoma. Cancer 2003; 98: 962-969. https://doi.org/10.1002/ cncr.11571

[27] ROSEN LS, GORDON D, KAMINSKI M, HOWELL A, BELCH A et al. Long-term efficacy and safety of zoledronic acid compared with pamidronate disodium in the treatment of skeletal complications in patients with advanced multiple myeloma or breast carcinoma: a randomized, double-blind, multicenter, comparative trial. Cancer 2003; 98: 1735-1744. https://doi.org/10.1002/cncr.11701

[28] SAAD F, GLEASON DM, MURRAY R, TCHEKMEDYIAN $S$, VENNER $P$ et al. A randomized, placebo-controlled trial of zoledronic acid in patients with hormone-refractory metastatic prostate carcinoma. J Natl Cancer I 2002; 94: 14581468. https://doi.org/10.1093/jnci/94.19.1458

[29] WANG F, CHEN W, CHEN H, MO L, JIN H et al. Comparison between zoledronic acid and clodronate in the treatment of prostate cancer patients with bone metastases. Med Oncol 2013; 30: 657. https://doi.org/10.1007/s12032-013-0657-x

[30] ROSEN LS, GORDON D, TCHEKMEDYIAN NS, YANAGIHARA R, HIRSH V et al. Long-term efficacy and safety of zoledronic acid in the treatment of skeletal metastases in patients with nonsmall cell lung carcinoma and other solid tumors: a randomized, Phase III, double-blind, placebocontrolled trial. Cancer 2004; 100: 2613-2621. https://doi. org/10.1002/cncr.20308

[31] TRIPATHY D, LICHINITZER M, LAZAREV A, MACLACHLAN SA, APFFELSTAEDT J et al. Oral ibandronate for the treatment of metastatic bone disease in breast cancer: efficacy and safety results from a randomized, double-blind, placebo-controlled trial. Ann Oncol 2004; 15: 743-750. https://doi.org/10.1093/annonc/mdh173

[32] BODY JJ, DIEL IJ, LICHINITZER M, LAZAREV A, PECHERSTORFER $M$ et al. Oral ibandronate reduces the risk of skeletal complications in breast cancer patients with metastatic bone disease: results from two randomised, placebocontrolled phase III studies. Brit J cancer 2004; 90: 11331137. https://doi.org/10.1038/sj.bjc.6601663

[33] BARRETT-LEE P, CASBARD A, ABRAHAM J, HOOD K, COLEMAN $R$ et al. Oral ibandronic acid versus intravenous zoledronic acid in treatment of bone metastases from breast cancer: a randomised, open label, non-inferiority phase 3 trial. Lancet Oncol 2014;15: 114-122. https://doi.org/10.1016/ s1470-2045(13)70539-4
[34] HERAS P, KARAGIANNIS S, KRITIKOS K, HATZOPOULOS A, MITSIBOUNAS D. Ibandronate is effective in preventing skeletal events in patients with bone metastases from colorectal cancer. Eur J cancer care 2007; 16: 539-542. https://doi.org/10.1111/j.1365-2354.2007.00808.x

[35] HERAS P, KRITIKOS K, HATZOPOULOS A, GEORGOPOULOU AP. Efficacy of ibandronate for the treatment of skeletal events in patients with metastatic breast cancer. Eur J cancer care 2009; 18: 653-656. https://doi.org/10.1111/ j.1365-2354.2008.00980.x

[36] ELOMAA I, BLOMQVIST C, PORKKA L, HOLMSTRÖM T, TAUBE $\mathrm{T}$ et al. Clodronate for osteolytic metastases due to breast cancer. Biomed Pharmacother 1988; 42: 111-116.

[37] ADAMI S, MIAN M. Clodronate therapy of metastatic bone disease in patients with prostatic carcinoma. Recent Results Cancer Res 1989; 116: 67-72. https://doi.org/10.1007/978-3642-83668-8_6

[38] SAAD F, GLEASON DM, MURRAY R, TCHEKMEDYIAN $S$, VENNER $P$ et al. Long-term efficacy of zoledronic acid for the prevention of skeletal complications in patients with metastatic hormone-refractory prostate cancer. J Natl Cancer I 2004; 96: 879-882. https://doi.org/10.1093/jnci/djh141

[39] WANG RL, TIAN JZ, ZHANG SH, WANG T, BIAN L et al. An exploratory study of second-line treatment of bone pain in the patients of metastatic breast cancer with a loading dose of ibandronate. Chin J Bone Joint 2015; 4: 302-305. https:// doi.org/10.3969/j.issn.2095-252X.2015.04.015

[40] STOPECK AT, LIPTON A, BODY JJ, STEGER GG, TONKIN K et al. Denosumab compared with zoledronic acid for the treatment of bone metastases in patients with advanced breast cancer: a randomized, double-blind study. J Clin Oncol 2010; 28: 5132-5139. https://doi.org/10.1200/ jco.2010.29.7101

[41] FIZAZI K, CARDUCCI M, SMITH M, DAMIÃO R, BROWN $J$ et al. Denosumab versus zoledronic acid for treatment of bone metastases in men with castration-resistant prostate cancer: a randomised, double-blind study. Lancet 2011; 377: 813-822. https://doi.org/10.1016/s0140-6736(10)62344-6

[42] RAJE N, TERPOS E, WILLENBACHER W, SHIMIZU K, GARCÍA-SANZ R et al. Denosumab versus zoledronic acid in bone disease treatment of newly diagnosed multiple myeloma: an international, double-blind, double-dummy, randomised, controlled, phase 3 study. Lancet Oncol 2018; 19: 370-381. https://doi.org/10.1016/s1470-2045(18)30072-x

[43] HENRY DH, COSTA L, GOLDWASSER F, HIRSH V, HUNGRIA V et al. Randomized, double-blind study of denosumab versus zoledronic acid in the treatment of bone metastases in patients with advanced cancer (excluding breast and prostate cancer) or multiple myeloma. J Clin Oncol 2011; 29: 1125-1132. https://doi.org/10.1200/jco.2010.31.3304

[44] HENRY D, VADHAN-RAJ S, HIRSH V, VON MOOS R, HUNGRIA V et al. Delaying skeletal-related events in a randomized phase 3 study of denosumab versus zoledronic acid in patients with advanced cancer: an analysis of data from patients with solid tumors. Support Care Cancer 2014; 22: 679-687. https://doi.org/10.1007/s00520-013-2022-1 
[45] LIPTON A, FIZAZI K, STOPECK AT, HENRY DH, BROWN JE et al. Superiority of denosumab to zoledronic acid for prevention of skeletal-related events: a combined analysis of 3 pivotal, randomised, phase 3 trials. Eur J Cancer 2012; 48: 3082-3092. https://doi.org/10.1016/j.ejca.2012.08.002

[46] IMAI H, SAIJO K, YAMADA H, OHUCHI K, OKADA Y et al. Efficacy and safety of denosumab versus zoledronic acid in delaying skeletal-related events in patients with gastrointestinal cancer, pancreas-biliary system cancer, and other rare cancers. J Bone Oncol 2016; 6: 37-40. https://doi. org/10.1016/j.jbo.2016.10.002

[47] SCAGLIOTTI GV, HIRSH V, SIENA S, HENRY DH, WOLL $\mathrm{PJ}$ et al. Overall survival improvement in patients with lung cancer and bone metastases treated with denosumab versus zoledronic acid: subgroup analysis from a randomized phase 3 study. J Thorac Oncol 2012; 7: 1823-1829. https:// doi.org/10.1097/JTO.0b013e31826aec2b

[48] UDAGAWA H, NIHO S, KIRITA K, UMEMURA S, MATSUMOTO $S$ et al. Impact of denosumab use on the survival of untreated non-squamous non-small cell lung cancer patients with bone metastases. J Cancer Res Clinical 2017; 143: 1075-1082. https://doi.org/10.1007/s00432-017-2350-5

[49] NOVINEC M, LENARČIČ B. Cathepsin K: a unique collagenolytic cysteine peptidase. Biol Chem 2013; 394: 11631179. https://doi.org/10.1515/hsz-2013-0134

[50] DEJICA VM, MORT JS, LAVERTY S, PERCIVAL MD, ANTONIOU J et al. Cleavage of type II collagen by cathepsin $\mathrm{K}$ in human osteoarthritic cartilage. Am J Pathol 2008; 173: 161-169. https://doi.org/10.2353/ajpath.2008.070494

[51] CHRISTENSEN J, SHASTRI VP. Matrix-metalloproteinase- 9 is cleaved and activated by cathepsin K. BMC Res Notes 2015; 8: 322. https://doi.org/10.1186/s13104-015-1284-8

[52] MCCLUNG MR, O’DONOGHUE ML, PAPAPOULOS SE, BONE H, LANGDAHL B et al. Odanacatib for the treatment of postmenopausal osteoporosis: results of the LOFT multicentre, randomised, double-blind, placebo-controlled trial and LOFT Extension study. Lancet Diabetes Endocrinol 2019; 7: 899-911. https://doi.org/10.1016/s22138587(19)30346-8

[53] VASHUM Y, PREMSINGH R, KOTTAISWAMY A, SOMA $\mathrm{M}$, PADMANABAN A et al. Inhibitory effect of cathepsin $\mathrm{K}$ inhibitor (ODN-MK-0822) on invasion, migration and adhesion of human breast cancer cells in vitro. Mol Biol Rep 2021; 48: 105-116. https://doi.org/10.1007/s11033-02005951-0

[54] VASHUM Y, KOTTAISWAMY A, BUPESH G, SINGH RP, KALAISELVAN P et al. Inhibitory Effects of Cathepsin K Inhibitor (ODN-MK-0822) on the Paracrine Pro-Osteoclast Factors of Breast Cancer Cells. Curr Mol Pharmacol 2021; https://doi.org/10.2174/1874467214666210211162118

[55] JENSEN AB, WYNNE C, RAMIREZ G, HE W, SONG Y et al. The cathepsin $\mathrm{K}$ inhibitor odanacatib suppresses bone resorption in women with breast cancer and established bone metastases: results of a 4-week, double-blind, randomized, controlled trial. Clin Breast Cancer 2010; 10: 452-458. https://doi.org/10.3816/CBC.2010.n.059
[56] ISHIZAWAR R, PARSONS SJ. c-Src and cooperating partners in human cancer. Cancer cell 2004; 6: 209-214. https:// doi.org/10.1016/j.ccr.2004.09.001

[57] KIM JH, KIM K, KIM I, SEONG S, KIM N. c-Src-Dependent and -Independent Functions of Matk in Osteoclasts and Osteoblasts. J Immunol 2018; 200: 2455-2463. https://doi. org/10.4049/jimmunol.1700582

[58] DESTAING O, SANJAY A, ITZSTEIN C, HORNE WC, TOOMRE $\mathrm{D}$ et al. The tyrosine kinase activity of $\mathrm{c}$-Src regulates actin dynamics and organization of podosomes in osteoclasts. Mol Biol Cell 2008; 19: 394-404. https://doi. org/10.1091/mbc.e07-03-0227

[59] MITRI Z, NANDA R, BLACKWELL K, COSTELLOE CM, HOOD I et al. TBCRC-010: Phase I/II Study of Dasatinib in Combination with Zoledronic Acid for the Treatment of Breast Cancer Bone Metastasis. Clin Cancer Res 2016; 22: 5706-5712. https://doi.org/10.1158/1078-0432.Ccr-152845

[60] SCHOTT AF, BARLOW WE, VAN POZNAK CH, HAYES DF, MOINPOUR CM et al. Phase II studies of two different schedules of dasatinib in bone metastasis predominant metastatic breast cancer: SWOG S0622. Breast Cancer Res $\operatorname{Tr}$ 2016; 159: 87-95. https://doi.org/10.1007/s10549-0163911-z

[61] MORRIS PG, ROTA S, CADOO K, ZAMORA S, PATIL S et al. Phase II Study of Paclitaxel and Dasatinib in Metastatic Breast Cancer. Clin Breast Cancer 2018; 18: 387-394. https:// doi.org/10.1016/j.clbc.2018.03.010

[62] ARAUJO JC, TRUDEL GC, SAAD F, ARMSTRONG AJ, YU EY et al. Docetaxel and dasatinib or placebo in men with metastatic castration-resistant prostate cancer (READY): a randomised, double-blind phase 3 trial. Lancet Oncol 2013; 14: 1307-1316. https://doi.org/10.1016/s14702045(13)70479-0

[63] VULTUR A, BUETTNER R, KOWOLIK C, LIANG W, SMITH D et al. SKI-606 (bosutinib), a novel Src kinase inhibitor, suppresses migration and invasion of human breast cancer cells. Mol Cancer Ther 2008; 7: 1185-1194. https:// doi.org/10.1158/1535-7163.Mct-08-0126

[64] RABBANI SA, VALENTINO ML, ARAKELIAN A, ALI S, BOSCHELLI F. SKI-606 (Bosutinib) blocks prostate cancer invasion, growth, and metastasis in vitro and in vivo through regulation of genes involved in cancer growth and skeletal metastasis. Mol Cancer Ther 2010; 9: 1147-1157. https://doi. org/10.1158/1535-7163.Mct-09-0962

[65] JALLAL H, VALENTINO ML, CHEN G, BOSCHELLI F, ALI S et al. A Src/Abl kinase inhibitor, SKI-606, blocks breast cancer invasion, growth, and metastasis in vitro and in vivo. Cancer Res 2007; 67: 1580-1588. https://doi. org/10.1158/0008-5472.Can-06-2027

[66] CAMPONE M, BONDARENKO I, BRINCAT S, HOTKO Y, MUNSTER PN et al. Phase II study of single-agent bosutinib, a Src/Abl tyrosine kinase inhibitor, in patients with locally advanced or metastatic breast cancer pretreated with chemotherapy. Ann Oncol 2012; 23: 610-617. https:/doi. org/10.1093/annonc/mdr261 
[67] CLEMONS MJ, COCHRANE B, POND GR, CALIFARETTI N, CHIA SK et al. Randomised, phase II, placebo-controlled, trial of fulvestrant plus vandetanib in postmenopausal women with bone only or bone predominant, hormone-receptor-positive metastatic breast cancer (MBC): the OCOG ZAMBONEY study. Breast cancer Res $\operatorname{Tr} 2014$; 146: 153-162. https://doi.org/10.1007/s10549014-3015-6

[68] HEUSSCHEN R, MULLER J, BINSFELD M, MARTY C, PLOUGONVEN E et al. SRC kinase inhibition with saracatinib limits the development of osteolytic bone disease in multiple myeloma. Oncotarget 2016; 7: 30712-30729. https://doi.org/10.18632/oncotarget.8750

[69] DE VRIES TJ, MULLENDER MG, VAN DUIN MA, SEMEINS CM, JAMES N et al. The Src inhibitor AZD0530 reversibly inhibits the formation and activity of human osteoclasts. Mol Cancer Res 2009; 7: 476-488. https://doi. org/10.1158/1541-7786.Mcr-08-0219

[70] YANG JC, BAI L, YAP S, GAO AC, KUNG HJ et al. Effect of the specific Src family kinase inhibitor saracatinib on osteolytic lesions using the PC-3 bone model. Mol Cancer Ther 2010; 9: 1629-1637. https://doi.org/10.1158/1535-7163.Mct09-1058

[71] HANNON RA, FINKELMAN RD, CLACK G, IACONA RB, RIMMER $M$ et al. Effects of Src kinase inhibition by saracatinib (AZD0530) on bone turnover in advanced malignancy in a Phase I study. Bone 2012; 50: 885-892. https://doi. org/10.1016/j.bone.2011.12.017

[72] DANSON S, MULVEY MR, TURNER L, HORSMAN J, ESCOTT $\mathrm{K}$ et al. An exploratory randomized-controlled trial of the efficacy of the Src-kinase inhibitor saracatinib as a novel analgesic for cancer-induced bone pain. J Bone Oncol 2019; 19: 100261. https://doi.org/10.1016/j. jbo.2019.100261

[73] KECHAGIA JZ, IVASKA J, ROCA-CUSACHS P. Integrins as biomechanical sensors of the microenvironment. Nat Rev Molecular Cell Biol 2019; 20: 457-473. https://doi. org/10.1038/s41580-019-0134-2

[74] LI ZH, ZHOU Y, DING YX, GUO QL, ZHAO L. Roles of integrin in tumor development and the target inhibitors. Chinese journal of natural medicines 2019; 17: 241-251. https:// doi.org/10.1016/s1875-5364(19)30028-7

[75] ATA R, ANTONESCU CN. Integrins and Cell Metabolism: An Intimate Relationship Impacting Cancer. Int J Mol Sci 2017; 18: 189. https://doi.org/10.3390/ijms18010189

[76] WANG L, SONG L, LI J, WANG Y, YANG C et al. Bone sialoprotein- $\alpha \mathrm{v} \beta 3$ integrin axis promotes breast cancer metastasis to the bone. Cancer Sci 2019; 110: 3157-3172. https://doi.org/10.1111/cas.14172

[77] KWAKWA KA, STERLING JA. Integrin $\alpha v \beta 3$ Signaling in Tumor-Induced Bone Disease. Cancers 2017; 9: 84. https:// doi.org/10.3390/cancers9070084

[78] LI N, ZHANG JP, GUO S, MIN J, LIU LL et al. Down-regulation of $\beta 3$-integrin inhibits bone metastasis of small cell lung cancer. Mol Biol Rep 2012; 39: 3029-3035. https://doi. org/10.1007/s11033-011-1065-y
[79] CARRON CP, MEYER DM, ENGLEMAN VW, RICO JG, RUMINSKI PG et al. Peptidomimetic antagonists of alphavbeta3 inhibit bone resorption by inhibiting osteoclast bone resorptive activity, not osteoclast adhesion to bone. J Endocrinol 2000; 165: 587-598. https://doi.org/10.1677/ joe. 0.1650587

[80] PARK D, PARK CW, CHOI Y, LIN J, SEO DH et al. A novel small-molecule PPI inhibitor targeting integrin av $\beta 3$ osteopontin interface blocks bone resorption in vitro and prevents bone loss in mice. Biomaterials 2016; 98: 131-142. https://doi.org/10.1016/j.biomaterials.2016.05.007

[81] BRADLEY DA, DAIGNAULT S, RYAN CJ, DIPAOLA RS, COONEY KA et al. Cilengitide (EMD 121974, NSC 707544) in asymptomatic metastatic castration resistant prostate cancer patients: a randomized phase II trial by the prostate cancer clinical trials consortium. Invest New Drug 2011; 29: 1432-1440. https://doi.org/10.1007/s10637-010-9420-8

[82] KHALILI P, ARAKELIAN A, CHEN G, PLUNKETT ML, BECK I et al. A non-RGD-based integrin binding peptide (ATN-161) blocks breast cancer growth and metastasis in vivo. Mol Cancer Ther 2006; 5: 2271-2280. https://doi. org/10.1158/1535-7163.Mct-06-0100

[83] ZHAO Y, BACHELIER R, TREILLEUX I, PUJUGUET P, PEYRUCHAUD $\mathrm{O}$ et al. Tumor alphavbeta3 integrin is a therapeutic target for breast cancer bone metastases. Cancer research 2007; 67: 5821-5830. https://doi.org/10.1158/00085472.Can-06-4499

[84] PANTANO F, CROSET M, DRIOUCH K, BEDNARZKNOLL N, IULIANI $M$ et al. Integrin alpha5 in human breast cancer is a mediator of bone metastasis and a therapeutic target for the treatment of osteolytic lesions. Oncogene 2021; 40: 1284-1299. https://doi.org/10.1038/s41388020-01603-6

[85] LI X, YANG J, BAO M, ZENG K, FU S et al. Wnt signaling in bone metastasis: mechanisms and therapeutic opportunities. Life Sci 2018; 208: 33-45. https://doi.org/10.1016/j. lfs.2018.06.036

[86] KAR S, JASUJA H, KATTI DR, KATTI KS. Wnt/ $\beta$-Catenin Signaling Pathway Regulates Osteogenesis for Breast Cancer Bone Metastasis: Experiments in an In Vitro Nanoclay Scaffold Cancer Testbed. ACS Biomater Sci Eng 2020; 6: 26002611. https://doi.org/10.1021/acsbiomaterials.9b00923

[87] HEATH DJ, CHANTRY AD, BUCKLE CH, COULTON L, SHAUGHNESSY JD et al. Inhibiting Dickkopf-1 (Dkk1) removes suppression of bone formation and prevents the development of osteolytic bone disease in multiple myeloma. J Bone Miner Res 2009; 24: 425-436. https://doi.org/10.1359/ jbmr.081104

[88] BU G, LU W, LIU CC, SELANDER K, YONEDA T et al. Breast cancer-derived Dickkopf1 inhibits osteoblast differentiation and osteoprotegerin expression: implication for breast cancer osteolytic bone metastases. Int J Cancer 2008; 123: 1034-1042. https://doi.org/10.1002/ijc.23625

[89] IYER SP, BECK JT, STEWART AK, SHAH J, KELLY KR ET AL. A Phase IB multicentre dose-determination study of BHQ880 in combination with anti-myeloma therapy and zoledronic acid in patients with relapsed or refractory multiple myeloma and prior skeletal-related events. Br J Haematol 2014; 167: 366-375. https://doi.org/10.1111/bjh.13056 
[90] COSMAN F, CRITTENDEN DB, ADACHI JD, BINKLEY N, CZERWINSKI E et al. Romosozumab Treatment in Postmenopausal Women with Osteoporosis. N EngI J Med 2016; 375: 1532-1543. https://doi.org/10.1056/NEJMoa1607948

[91] RECKNOR CP, RECKER RR, BENSON CT, ROBINS DA, CHIANG AY et al. The Effect of Discontinuing Treatment With Blosozumab: Follow-up Results of a Phase 2 Randomized Clinical Trial in Postmenopausal Women With Low Bone Mineral Density. J Bone Miner Res 2015; 30: 17171725. https://doi.org/10.1002/jbmr.2489

[92] GLORIEUX FH, DEVOGELAER JP, DURIGOVA M, GOEMAERE S, HEMSLEY S et al. BPS804 Anti-Sclerostin Antibody in Adults With Moderate Osteogenesis Imperfecta: Results of a Randomized Phase 2a Trial. J Bone Miner Res 2017; 32: 1496-1504. https://doi.org/10.1002/jbmr.3143

[93] HU GF, WANG C, HU GX, WU G, ZHANG C et al. AZD3463, an IGF-1R inhibitor, suppresses breast cancer metastasis to bone via modulation of the PI3K-Akt pathway. Ann Transl Med 2020; 8: 336. https://doi.org/10.21037/ atm.2020.02.110

[94] Di L, Liu LJ, Yan YM, Fu R, Li Y et al. Discovery of a natural small-molecule compound that suppresses tumor EMT, stemness and metastasis by inhibiting TGF $\beta / B M P$ signaling in triple-negative breast cancer. J Exp Clin Cancer Res 2019; 38: 134. https://doi.org/10.1186/s13046-019-1130-2

[95] FOURNIER PG, JUÁREZ P, JIANG G, CLINES GA, NIEWOLNA $M$ et al. The TGF- $\beta$ Signaling Regulator PMEPA1 Suppresses Prostate Cancer Metastases to Bone. Cancer cell 2015; 27: 809-821. https://doi.org/10.1016/j. ccell.2015.04.009

[96] ZHU J, TANG Y, WU Q, JI YC, KANG FW. Mechanism of participation of osteocytes in the formation of osteoclasts under hypoxia. West China journal of stomatology 2019; 37: 463-468. https://doi.org/10.7518/hxkq.2019.05.002

[97] ZHU J, TANG Y, WU Q, JI YC, FENG ZF et al. HIF-1 $\alpha$ facilitates osteocyte-mediated osteoclastogenesis by activating JAK2/STAT3 pathway in vitro. J Cell Physiol 2019; 234: 21182-21192. https://doi.org/10.1002/jcp.28721

[98] TANG ZN, ZHANG F, TANG P, QI XW, JIANG J. Hypoxia induces RANK and RANKL expression by activating HIF-1a in breast cancer cells. Biochem Biophys Res Commun 2011; 408: 411-416. https://doi.org/10.1016/j.bbrc.2011.04.035

[99] UTTING JC, ROBINS SP, BRANDAO-BURCH A, ORRISS IR, BEHAR J et al. Hypoxia inhibits the growth, differentiation and bone-forming capacity of rat osteoblasts. Exp Cell Res 2006; 312: 1693-1702. https://doi.org/10.1016/j.yexcr.2006.02.007
[100] TODD VM, JOHNSON RW. Hypoxia in bone metastasis and osteolysis. Cancer lett 2020; 489: 144-154. https://doi. org/10.1016/j.canlet.2020.06.004

[101] XU N, LIU H, QU F, FAN J, MAO K et al. Hypoxia inhibits the differentiation of mesenchymal stem cells into osteoblasts by activation of Notch signaling. Exp Mol Pathol 2013; 94: 33-39. https://doi.org/10.1016/j.yexmp.2012.08.003

[102] AGGARWAL A, PRINZ-WOHLGENANNT M, GRÖSCHEL C, TENNAKOON S, MESHCHERYAKOVA A et al. The calcium-sensing receptor suppresses epithelialto-mesenchymal transition and stem cell- like phenotype in the colon. Mol Cancer 2015; 14: 61. https://doi.org/10.1186/ s12943-015-0330-4

[103] AGGARWAL A, PRINZ-WOHLGENANNT M, TENNAKOON S, HÖBAUS J, BOUDOT C et al. The calcium-sensing receptor: A promising target for prevention of colorectal cancer. Biochim Biophys Acta 2015; 1853: 2158-2167. https://doi.org/10.1016/j.bbamcr.2015.02.011

[104] FENG J, XU X, LI B, BROWN E, FARRIS AB et al. Prostate cancer metastatic to bone has higher expression of the calcium-sensing receptor (CaSR) than primary prostate cancer. Receptors Clin Investig 2014; 1: e270. https://doi. org/10.14800/rci.270

[105] LIU L, FAN Y, CHEN Z, ZHANG Y, YU J. CaSR Induces Osteoclast Differentiation and Promotes Bone Metastasis in Lung Adenocarcinoma. Front Oncol 2020; 10: 305. https:// doi.org/10.3389/fonc.2020.00305

[106] FREES S, BREUKSCH I, HABER T, BAUER HK, CHAVEZMUNOZ C et al. Calcium-sensing receptor (CaSR) promotes development of bone metastasis in renal cell carcinoma. Oncotarget 2018; 9: 15766-15779. https://doi.org/10.18632/oncotarget. 24607

[107] BOUDOT C, HÉNAUT L, THIEM U, GERACI S, GALANTE $\mathrm{M}$ et al. Overexpression of a functional calcium-sensing receptor dramatically increases osteolytic potential of MDAMB-231 cells in a mouse model of bone metastasis through epiregulin-mediated osteoprotegerin downregulation. Oncotarget 2017; 8: 56460-56472. https://doi.org/10.18632/oncotarget.16999

[108] XING L, EBETINO FH, BOECKMAN RK, SRINIVASAN $\mathrm{V}$, TAO J et al. Targeting anti-cancer agents to bone using bisphosphonates. Bone 2020; 138: 115492. https://doi. org/10.1016/j.bone.2020.115492 